\title{
Groundwater supports intermittent-stream food webs
}

\author{
Ryan M. Burrows ${ }^{1,6}$, Helen Rutlidge ${ }^{2,3,7}$, Dominic G. Valdez ${ }^{1,8}$, Michael Venarsky ${ }^{1,9}$, Nick R. Bond ${ }^{4,1,10}$, \\ Martin S. Andersen ${ }^{2,3,11}$, Brian Fry ${ }^{1,12}$, Stefan M. Eberhard ${ }^{2,5,13}$, and Mark J. Kennard ${ }^{1,14}$
}

${ }^{1}$ Australian Rivers Institute, Griffith University, Nathan, Queensland, Australia 4111

${ }^{2}$ Connected Waters Initiative Research Centre, UNSW Sydney, Australia 2093

${ }^{3}$ School of Civil and Environmental Engineering, UNSW Sydney, Australia 2032

${ }^{4}$ Murray-Darling Freshwater Research Centre, La Trobe University, Wodonga, Victoria, Australia 3690

${ }^{5}$ Subterranean Ecology, Coningham, Tasmania, Australia 7054

\begin{abstract}
Stream food webs are changing in response to anthropogenic stressors, such as nutrient enrichment and water extraction. One way to monitor these changes is to examine shifts in the relative importance of autotrophic and detrital energetic pathways in food webs. This understanding is particularly pertinent in intermittent streams whose prevalence is projected to increase because of a changing climate and groundwater extraction. We used the stable-isotope values $\left(\delta^{13} \mathrm{C}\right.$ and $\left.\delta^{15} \mathrm{~N}\right)$ of autotrophic and detrital basal resources and the tissue of consumers to examine the relative importance of these 2 energetic pathways during wet and dry phases in 5 groundwaterinfluenced intermittent streams. In addition, we used surface-water biogeochemical data to estimate the use of groundwater-derived dissolved inorganic C (DIC) in food webs. Autotrophic basal resources were the dominant $C$ source for primary consumers during wet $(>95 \%$, on average) and dry $(>77 \%$, on average) hydrological phases.

${ }^{13} \mathrm{C}$-depleted autotrophs and consumers and negative correlations between the $\delta^{13} \mathrm{C}$ values of autotrophs and consumers with aqueous $\mathrm{CO}_{2}$ concentrations, indicated that primary producers probably are assimilating microbial respired $\mathrm{CO}_{2}$ from groundwater. Overall, we suggest that groundwater discharge is probably central to foodweb productivity in these streams by extending the duration of wetted habitat for autotrophic growth during dry phases and by delivering dissolved resources that potentially contribute to the energetic base of producers and consumers. Consequently, extended periods of reduced flow (and cease-to-flow events) caused by groundwater extraction or changed climatic conditions may reduce the overall productivity of groundwater-influenced intermittent streams.
\end{abstract}

Key words: food webs, stable isotopes, groundwater, intermittent stream, carbon, algae, carbon dioxide, detritus, macrophytes, periphyton, consumers

Understanding which resources sustain the energy requirements of consumers and what factors limit the availability of those basal resources is fundamental when assessing ecological patterns and processes (Brett et al. 2017). Consumers ultimately obtain their resources from autotrophic and detrital energetic pathways (Moore et al. 2004, Shurin et al. 2006). Autotrophic $C$ includes all $C$ converted from an inorganic molecule to organic matter (Shurin et al. 2006), whereas detrital $\mathrm{C}$ is nonliving autotrophic material at various stages of decomposition (Moore et al. 2004). In river networks, the relative importance of these 2 energetic pathways is expected to vary along a spatial continuum, with a reduc- tion in detrital resources as channel order increases because of reduced linkages between terrestrial-aquatic habitats (i.e., fewer organic matter inputs from overhanging vegetation) and increased light availability, which promotes autotrophic production (Vannote et al. 1980). At more local scales, such as within replicates of the same stream order or type, the relative importance of detrital and autotrophic energetic pathways may vary spatially and temporally because of patchiness in vegetation cover and seasonal- and human-driven changes in resource supply (i.e., light availability and organic matter flux). In addition, the relative importance of these 2 energetic pathways depends on specific life histories of

E-mail addresses: ${ }^{6}$ r.burrows@griffith.edu.au; ${ }^{7}$ h.rutlidge@unsw.edu.au; ${ }^{8}$ d.valdez@griffith.edu.au; ${ }^{9}$ mvenarsky@gmail.com; ${ }^{10}$ n.bond@latrobe.edu.au; ${ }^{11}$ m.andersen@unsw.edu.au; ${ }^{12}$ b.fry@griffith.edu.au; ${ }^{13}$ stefan@subterraneanecology.com.au; ${ }^{14}$ m.kennard@griffith.edu.au

DOI: 10.1086/696533. Received 14 July 2017; Accepted 11 November 2017; Published online 9 January 2018.

Freshwater Science. 2018. 37(1):42-53. @ 2018 by The Society for Freshwater Science. 
taxa (i.e., growth rates and feeding strategies) and the scale of assessment (i.e., trophic position and ecosystem extent) (Moore et al. 2004, Shurin et al. 2006). Last, 'multichannel' feeding, the direct and indirect consumption of both autotrophic and detrital resources, is common in nature and complicates the quantification of these energetic pathways (Polis and Strong 1996, Wolkovich et al. 2014). Recognizing the dynamic nature and importance of autotrophic and detrital energetic pathways, the mechanisms controlling spatiotemporal variation in these pathways are of considerable interest. A better processes-based understanding should allow predictions of how food webs may respond to variation in the availability of basal resources caused by natural and anthropogenic changes in riparian, catchment, and global environmental condition.

The importance of autotrophic $\mathrm{C}$ resources to higher trophic levels has been the focus of considerable scientific attention, but only a few researchers have reversed their focus to investigate where this inorganic $\mathrm{C}$ originates (Finlay 2004, Gray et al. 2011). This origin is most relevant for primary producers that can assimilate various forms of dissolved inorganic $\mathrm{C}$ (DIC) including bicarbonate $\left(\mathrm{HCO}_{3}{ }^{-}\right)$ directly from the water column in aquatic environments (Raven 1970). However, aqueous $\mathrm{CO}_{2}\left(\mathrm{CO}_{2 \mathrm{aq}}\right)$ is the main form of DIC assimilated by aquatic primary producers because unlike $\mathrm{HCO}_{3}{ }^{-}, \mathrm{CO}_{2 \mathrm{aq}}$ is a neutral, nonpolar molecule that can readily diffuse across biological membranes (Cooper and Hausman 2013). $\mathrm{CO}_{2 \mathrm{aq}}$ concentrations in streams are determined by a balance among the processes of atmospheric exchange, in-stream respiration and photosynthesis, and inputs of inorganic-C-rich groundwater (Dinsmore et al. 2013). Groundwater is often enriched in $\mathrm{CO}_{2 \mathrm{aq}}$ because of soil or aquifer microbial respiration (Appelo and Postma 2005), and streams and rivers with high groundwater inputs can be supersaturated in $\mathrm{CO}_{2 \mathrm{aq}}$ (relative to the atmosphere) (Jones and Mulholland 1998, Hope et al. 2004). Algae can assimilate this microbially respired $\mathrm{CO}_{2}$, leading to aquatic food webs that can derive $>50 \%$ of their C supply from groundwater DIC (Gray et al. 2011). Therefore, groundwater contributions to streams and rivers influence their hydrologic characteristics by decreasing the duration of cease-to-flow periods for benthic environments between rainfall events (Tallaksen 1995) and deliver DIC that isotopically labels food webs and allows tracing of groundwater influences (Finlay 2004, Gray et al. 2011).

In streams, changes in hydrology appear to be an important factor dictating shifts between dominance of autotrophic vs detrital pathways in food webs, especially for intermittent streams where flow is dynamic and the wetted environment is often reduced to a series of isolated water holes (Steward et al. 2012). Autotrophic resources generally become more important during periods of low flow and surface-flow cessation because the availability of dissolved and particulate detritus in streams is mediated by overland and subsurface flow paths (Huryn et al. 2001, Fin- lay et al. 2002, Bunn et al. 2003, Reid et al. 2008). Therefore, stream intermittency is associated with greater autochthony, which may be most noticeable during periods of surface-flow cessation. However, detrital resources might remain important food and energy sources through time, and presumably with changes in flow, in heavily shaded intermittent stream reaches, as has been observed in perennial streams (Wallace et al. 1997, Hall et al. 2001).

We tested how flow intermittency influences the contribution of detrital vs autotrophic $C$ resources supporting aquatic food webs. We hypothesized that the energetic contribution of autotrophic resources would be greater during the dry season, with detrital resources becoming more important during the wet season. We addressed this question by sampling basal resources and the tissue of consumers and measuring the ratios of stable isotopes of $\mathrm{C}\left({ }^{13} \mathrm{C} /{ }^{12} \mathrm{C}=\right.$ $\left.\delta^{13} \mathrm{C}\right)$ and $\mathrm{N}\left({ }^{15} \mathrm{~N} /{ }^{14} \mathrm{~N}=\delta^{15} \mathrm{~N}\right)$ in wet and dry periods in 5 intermittent streams in eastern Australia. In addition, we sought to estimate the importance of groundwater subsidies to stream food webs by investigating links between DIC concentrations and the $\delta^{13} \mathrm{C}$ of primary producers and consumers. Stream intermittency is predicted to increase globally as a result of climate change and increasing groundwater extraction (Steward et al. 2012, Acuña et al. 2017), and there is a pressing need to understand better the consequences of reduced flow for ecosystem patterns and processes in intermittent and perennial systems, especially in areas subjected to potential groundwater drawdown.

\section{METHODS}

\section{Study area and design}

We sampled 100-m sections of 5 gravel-dominated intermittent streams in the upper Bremer River catchment in eastern Australia (Fig. S1). All streams were $2^{\text {nd }}$ or $3^{\text {rd }}$-order channels with catchment areas ranging from 5.97 to $45.3 \mathrm{~km}^{2}$ (Burrows et al. 2017). This region has a humid subtropical climate, as classified under the Köppen climate classification scheme (Peel et al. 2007). Precipitation and river discharge in this region are governed by a varying influence of tropical and temperate weather systems but are generally lowest from August to November (austral late winter to spring) and peaks in January to March (late summer to early autumn) (Mackay et al. 2014). All streams have characteristics typical of systems with substantial surface-water-groundwater connectivity, including high radon concentrations (Burrows et al. 2017; Table 1) and patches of active hyporheic exchange (data not shown). Riparian canopy cover was $78.0 \pm 2.0 \%$ (mean \pm $\mathrm{SD}$ ), and tree basal area was $13.0 \pm 4.5 \mathrm{~m}^{2} /$ ha (Andersen et al. 2016). Periphyton algal biomass (dry $=15.3 \pm$ $13 \mu \mathrm{g} / \mathrm{m}^{2}$, wet $=34.3 \pm 45 \mu \mathrm{g} / \mathrm{m}^{2}$ ) was often elevated but did not vary consistently among seasons in the study sites, with variability in algal dynamics probably related to the 


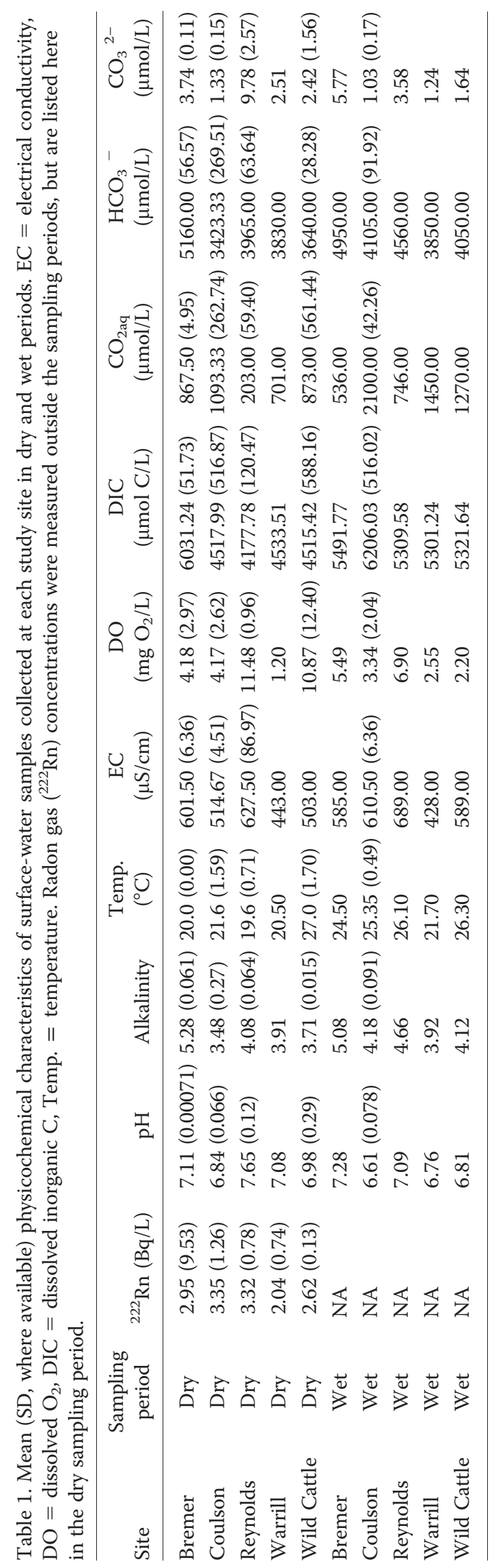


patchiness of residual wetted habitats, frequency and duration of drying, and local biogeochemical conditions (Andersen et al. 2016).

We sampled all study streams twice, once in the drier season and once in the wetter season, for foodweb basal resources and consumers (dry: 3-7 September 2015; wet: 710 March 2016) and physicochemical characteristics (dry: 7-9 October 2015; wet: 29 February-3 March 2016). The 12-wk average pool water-height data at each site before physicochemical sampling confirmed that our dry- and wet-season sampling occasions corresponded with low$(17.1 \pm 23 \mathrm{~cm})$ and high-water $(37.4 \pm 16 \mathrm{~cm})$ periods, respectively.

\section{Foodweb and biogeochemical sampling}

We used values of $\delta^{13} \mathrm{C}$ and $\delta^{15} \mathrm{~N}$ for inorganic and organic matter to investigate resource coupling and trophic linkages between basal resources and consumers in stream food webs. Basal resources have distinct $\delta^{13} \mathrm{C}$ values and these, along with $\delta^{15} \mathrm{~N}$ values, increase up the food chain (i.e., from resource to consumer) because of faster metabolic loss of the lighter isotopes $\left({ }^{12} \mathrm{C}\right.$ and $\left.{ }^{14} \mathrm{~N}\right)$ than the heavier isotopes $\left({ }^{13} \mathrm{C}\right.$ and ${ }^{15} \mathrm{~N}$ ) (DeNiro and Epstein 1978, 1981).

We collected triplicate individual samples of basal resources and consumers, whenever possible, from each study stream for measurement of $\delta^{13} \mathrm{C}$ and $\delta^{15} \mathrm{~N}$. Resources included coarse particulate organic matter (CPOM), submerged and emergent macrophytes (Alismataceae, Ceratophyllaceae, Polygonaceae, and Potamogetonaceae), and periphyton attached to rocks (epilithon) and wood (epixylon). We collected benthic macroinvertebrates, gastropods, and decapods via a combination of hand picking and 1- to 2-m dipnet sweeps of benthic surfaces and areas of littoral vegetation. We collected fish occasionally in the dipnet sweeps, but we also sampled them with an electrofisher. We collected a nonlethal fin clip, which is a reliable surrogate for muscle-tissue and whole-body isotope values in Australian freshwater fishes (Jardine et al. 2011), from each fish (maximum of 5 individuals per species per site and sampling occasion) for stable-isotope analysis. Primary consumers included Ephemeroptera (Baetidae, Caenidae, Leptophlebiidae), Trichoptera (Calamoceratidae, Ecnomidae, Hydropsychidae, and Leptoceridae), scraping Coleoptera (Psephenidae), and scraping Gastropoda (Planorbidae, Lymnaeidae). Secondary consumers or predatory macroinvertebrates included Hemiptera (Belostomatidae, Corixidae, Gelastocoridae, Gerridae, Hydrometridae, Notonectidae, Pleidae, Velidae), Odonata (Coenagrionidae, Corydalidae, Gomphidae, Libellulidae, Isostictidae, Megapodagrionidae), Coleoptera (Dytiscidae, Gyrinidae), Decapoda (Atyidae, Macrobrachium spp.) and Parastacidae (Cherax spp.). We classified fish as predatory (Fish-P: Anguilla australis,
Anguilla reinhardtii, Hypseleotris galii, Hypseleotris klunzingeri, Mogurnda adspersa, Tandanus tandanus) or omnivorous (Fish-O: Melanotaenia duboulayi, Craterocephalus marjoriae).

We used DIC biogeochemistry to trace groundwater $\mathrm{C}$, especially respired $\mathrm{CO}_{2}$ from microbial mineralization of organic matter, through aquatic food webs. Primary producers confined entirely within the water column use $\mathrm{CO}_{2 \mathrm{aq}}$ as their primary $\mathrm{C}$ source, but can use $\mathrm{HCO}_{3}{ }^{-}$ (Finlay 2004). The $\delta^{13} \mathrm{C}$ of primary producers generally decreases with increasing $\mathrm{CO}_{2 \mathrm{aq}}$ concentrations because of: 1) the effects on the $\delta^{13} \mathrm{C}$ of $\mathrm{CO}_{2 \mathrm{aq}}$, which becomes more negative when respiration exceeds production, or in groundwater-influenced systems that are rich in soil respired $\mathrm{CO}_{2 \mathrm{aq}}$ (Finlay 2004); and 2) elevated photosynthetic fractionation that lowers $\delta^{13} \mathrm{C}$ by up to $29 \%$ when the enzyme ribulose bisphosphate carboxylase oxygenase catalyzes photosynthetic C fixation (Roeske and O'Leary 1984). The assimilation of soil-respired $\mathrm{CO}_{2}$ by primary producers can be identified in aquatic ecosystems because soilrespired $\mathrm{CO}_{2}$, which is transported in subsurface flow paths to surface waters, typically has a much lower $\delta^{13} \mathrm{C}$ value $(\sim-23 \%)$ than atmospheric $\mathrm{CO}_{2}(\sim-8 \%)$ (Finlay 2004, Gray et al. 2011). Soil-respired $\mathrm{CO}_{2}$ has lower $\delta^{13} \mathrm{C}$ that resembles the $\delta^{13} \mathrm{C}$ value of vegetation in $\mathrm{C}_{3}$-dominated landscapes (Gray et al. 2011). Consequently, low $\delta^{13} \mathrm{C}$ values for primary producers (and the entire food web) would indicate that groundwater-derived DIC is being used by stream organisms. Water-rock interactions in aquifers, predominantly by carbonate minerals (e.g., $\mathrm{CaCO}_{3}$ ), can increase the $\delta^{13} \mathrm{C}$ value of groundwater DIC and can, in extreme cases, approach a $\delta^{13} \mathrm{C}$ value of $0 \%$ (Appelo and Postma 2005). The presence of $C_{4}$ vegetation in the landscape, which has a higher $\delta^{13} \mathrm{C}$ value than $\mathrm{C}_{3}$ vegetation, also can increase the $\delta^{13} \mathrm{C}$ value of groundwater DIC (Finlay and Kendall 2007). In such cases, the groundwaterderived DIC may lead to higher $\delta^{13} \mathrm{C}$ values of primary and secondary consumers, and thus, higher $\delta^{13} \mathrm{C}$ values do not necessarily preclude a groundwater source.

We collected surface-water samples for DIC measurement with a peristaltic pump connected to a polyethylene tube installed 5 to $10 \mathrm{~cm}$ above the streambed. We took samples during daylight hours at representative locations in the study reaches. We measured dissolved $\mathrm{O}_{2}(\mathrm{DO})$, electrical conductivity (EC), $\mathrm{pH}$, and water temperature with HQ40D water-quality meters and probes (HACH, Loveland, Colorado) in an in-line Sheffield Lfc Flow-through cell (Waterra-In-Situ, Shirley, UK) isolated from the atmosphere. Once these variables stabilized, we collected water samples with a 50 -mL Luer Lock $^{\ominus}$ syringe from a sampling port upstream of the flow-cell to minimize gas exchange with the atmosphere. The syringes were capped and kept cool and dark for alkalinity analysis the same evening. We collected 3 replicate 2-L surface-water samples, with zero 
headspace, from each stream during a period of surfacewater flow for ${ }^{222} \mathrm{Rn}$ activity measurements.

\section{Laboratory sample preparation and analysis}

We rinsed all plant and invertebrate collections with distilled water and removed any residual organic matter under a dissecting microscope. We classified all specimens to family, genus, or species where possible. We extracted muscle tissue from decapods with a scalpel. We dried all samples at $60^{\circ} \mathrm{C}$ for $24 \mathrm{~h}$ and then ground and homogenized them in a ball mill grinder. We weighed $\sim 5$-mg plant and 2 -mg animal tissue samples and combusted them in a Sercon Europa EA-GSL elemental analyzer (Sercon Limited, Crewe, UK). Sample gases were delivered to a Sercon Hydra 20-22 isotope ratio mass spectrometer for isotope and elemental analysis of $\mathrm{C}$ and $\mathrm{N}$. Elemental concentrations of $\mathrm{C}$ and $\mathrm{N}$ were used to calculate the molar $\mathrm{C}: \mathrm{N}$ ratios of basal resources, wherein low $\mathrm{C}: \mathrm{N}$ ratios indicate good nutritional quality for consumers. We calibrated working standards against internal standards $\mathrm{CH}$, CH7, N1, and $\mathrm{N} 2$ from the International Atomic Energy Agency (IAEA) and had elemental compositions that approximately matched the samples (44\% C and 11\% $\mathrm{N}$ for animal tissues, $41 \% \mathrm{C}$ and $2 \% \mathrm{~N}$ for plant tissues).

We measured the alkalinity of surface-water samples by the Gran titration technique (Stumm and Morgan 1996) with $0.16 \mathrm{~N}$ sulfuric acid and a digital titrator (HACH). The samples were filtered $(0.45-\mu \mathrm{m}$ pore size $)$ to remove suspended solids before titration. We calculated DIC and individual species concentrations $\left(\mathrm{CO}_{2}, \mathrm{HCO}_{3}{ }^{-}\right.$, and $\left.\mathrm{CO}_{3}{ }^{2-}\right)$ by a PHREEQC speciation (Parkhurst and Appelo 2003) based on the field-measured $\mathrm{pH}$ and the alkalinity values, assuming that the alkalinity is entirely dominated by inorganic C: alkalinity $=\left[\mathrm{OH}^{-}\right]-\left[\mathrm{H}^{+}\right]+\left[\mathrm{HCO}_{3}{ }^{-}\right]+2\left[\mathrm{CO}_{3}{ }^{2-}\right]$.

We measured ${ }^{222} \mathrm{Rn}$ activity of water samples using a RAD-7 radon detector (Durridge Company, Billerica, Massachusetts), following the methods of Burnett and Dulaiova (2003), within $24 \mathrm{~h}$ of sample collection. Final ${ }^{222} \mathrm{Rn}$ values were back-calculated to account for radioactive decay from time of sampling. ${ }^{222} \mathrm{Rn}$ is an excellent tracer to identify areas of significant groundwater influence or hyporheic exchange because subsurface water is very enriched in ${ }^{222} \mathrm{Rn}$ compared to surface waters (typically $\geq 1000 \times$ ), it is chemically unreactive, volatile, and has a short half-life $\left(\mathrm{t}_{1 / 2}=\right.$ $3.83 \mathrm{~d}$ ) (Burnett and Dulaiova 2003). ${ }^{222} \mathrm{Rn}$ concentrations in rainwater have been reported to be $\sim 0.1 \mathrm{~Bq} / \mathrm{L}$ (Andrews and Wood 1972), and values in excess of this indicate groundwater discharge or subsurface-surface water exchange.

\section{Data treatment and statistical analyses}

We assessed changes to consumer-resource coupling among wet and dry sampling periods with complimentary approaches. First, we undertook a gradient or shift approach to visualize and assess significant flow-influenced changes in the $\delta^{13} \mathrm{C}$ values of basal food resources, consumers, and the entire food web (i.e., mean of all basal food resources and consumers). We subtracted mean dry-season $\delta^{13} \mathrm{C}$ values from mean wet-season $\delta^{13} \mathrm{C}$ values, yielding $\Delta^{13} \mathrm{C}$. Basal resource or consumer values that deviate from $\Delta^{13} \mathrm{C}=0 \%$ indicate temporal variation in $\delta^{13} \mathrm{C}$ values. Coupled positive or negative $\delta^{13} \mathrm{C}$ values for a basal resource and consumer may indicate a strong reliance of that consumer on that particular basal resource. In this analysis, shifts in groundwater inputs and inorganic $C$ supplies would result in shifts in food-resource isotopes, with these altered food signals passed up through the food web to consumers.

Second, we used a 3-source linear mixing model (IsoError) that incorporates dietary source and mixing variability (Phillips and Gregg 2001) to solve the dietary contributions of primary consumers from potential food sources (CPOM, macrophytes and periphyton, and filamentous algae). Macrophyte and periphyton had similar $\delta^{13} \mathrm{C}$ and $\delta^{15} \mathrm{~N}$ values and were pooled for each sampling period to enable this 3-source model. In each IsoError model, we corrected primary consumers in a bivariate space for enrichment arising from trophic fractionation (Ben-David et al. 1997). An initial trophic enrichment factor (TEF) of 0.2 for $\delta^{13} \mathrm{C}$ and 0.6 for $\delta^{15} \mathrm{~N}$ was chosen for primary consumers because these values have been recommended or previously used for local foodweb investigations (Bunn et al. 2003, 2013). However, because TEFs have been termed the "the weakest link in the application of stable-isotope mixing models to ecological questions of diet reconstruction" (Bond and Diamond 2011, p. 1017), we ran additional IsoError models using 2 alternative TEFs $\left(\delta^{13} \mathrm{C}=0.2\right.$ and $\delta^{15} \mathrm{~N}=0.6 ; \delta^{13} \mathrm{C}=$ 0.3 and $\delta^{15} \mathrm{~N}=0.7 ; \delta^{13} \mathrm{C}=0.4$ and $\delta^{15} \mathrm{~N}=0.8$ ). Use of a variety of TEFs allowed us to assess the sensitivity of our data set to variation in the TEF applied to consumers. We report dietary contributions based on a mean of the 3 TEFs applied, but dietary contributions for the individual TEFs are available in Fig. S2. TEF-corrected dual-isotope plots for the primary consumers and basal food resources are available in Fig. S3.

As a check on the IsoError output, we also used a Bayesian mixing model (MixSIAR) (Stock and Semmens 2013) to estimate the dietary contributions of 3 basal food resources to primary consumers in wet and dry sampling seasons. MixSIAR produces probability distributions of the contributions of basal resources to consumer isotope values while accounting for variability in the $\delta^{13} \mathrm{C}$ and $\delta^{15} \mathrm{~N}$ of basal resources, consumers, and the trophic enrichment factors applied. We used uninformative (equally likely) priors for each model. Uninformative (equally likely) priors often shift the posterior or dietary contribution outcome toward a generalist diet (Moore and Semmens 2008). For all MixSIAR Bayesian mixing models, we set the Markov Chain-Monte Carlo parameters at the 'long' test length (chain length = 
300,000; burn-in $=200,000$; thin $=100$; chains $=3$ ) and applied the following TEFs and SDs: $\delta^{13} \mathrm{C}=0.2 \pm 1.3$ and $\delta^{15} \mathrm{~N}=0.6 \pm 1.8$.

We could not use mixing models confidently to estimate the dietary contributions for high-order consumers (i.e., fish) because TEF-corrected isotope values for consumers based on TEFs estimated for consumers locally (Bunn et al. 2013) fell outside the basal food resource triangles in dual-isotope plots (plots not shown). Failure to obtain the correct TEF for fish will lead to error in trophic position estimation and, thus, estimation of dietary contributions (Blanke et al. 2017). Thus, better estimates of TEFs for higher-order consumers from methods including gutcontent assessment or compound-specific (amino acids) stable-isotope analysis are required.

We used Spearman's rank-order tests to investigate the relationships between the mean concentrations of DIC, $\mathrm{CO}_{2}, \mathrm{HCO}_{3}{ }^{-}$, and $\mathrm{CO}_{3}{ }^{2-}$ with the average $\delta^{13} \mathrm{C}$ values of primary producers, primary consumers, and the entire food web (mean of all basal resources and consumers). An inverse correlation between $\mathrm{CO}_{2}$ and $\delta^{13} \mathrm{C}$ values of the foodweb components above has been used to indicate contributions of groundwater-derived DIC to surface food webs (Finlay 2004). We performed correlations separately for each sampling period and for both trips combined. We performed linear-mixed effects models (LMMs) to assess these changes in $\delta^{13} \mathrm{C}$ values and DIC concentrations between dry and wet sampling periods with site as a random factor and sampling period as a fixed factor using the lme4 R package (Bates et al. 2015). All analyses were conducted in $\mathrm{R}$ (version 1.0.136; R Project for Statistical Computing, Vienna, Austria).

\section{RESULTS}

\section{Stable isotopes}

Basal food resources were isotopically distinct, with a large separation in mean $\delta^{15} \mathrm{~N}$ and $\delta^{13} \mathrm{C}$ values (Fig. 1A, B). Consumers generally had higher $\delta^{15} \mathrm{~N}$ values than basal food resources (Fig. 1A, B), with fish and decapods having the highest values. Overall, $\delta^{13} \mathrm{C}$ values for many of the basal food resources and consumers in our study were much lower than many algal or detrital-driven freshwater food webs from elsewhere, represented by the dashed line in Fig. 1A, B, which indicates the hypothetical trophic enrichment gradient for a food web based on the global mean for periphyton. Periphyton was the most nutritious basal food resource (mean $\pm \mathrm{SD}, \mathrm{C}: \mathrm{N}=10.0 \pm 2.12$ ), followed by filamentous algae $(\mathrm{C}: \mathrm{N}=16.9 \pm 5.46)$, macrophytes $(\mathrm{C}: \mathrm{N}=22.6 \pm 7.83)$, and $\mathrm{CPOM}(\mathrm{C}: \mathrm{N}=37.8 \pm 14.4)$.

\section{Consumer-resource coupling}

$\delta^{13} \mathrm{C}$ values for periphyton in the wet sampling period $\left(\delta^{13} \mathrm{C}=-29.4 \%\right.$ o \pm 3.00$)$ were significantly higher (by

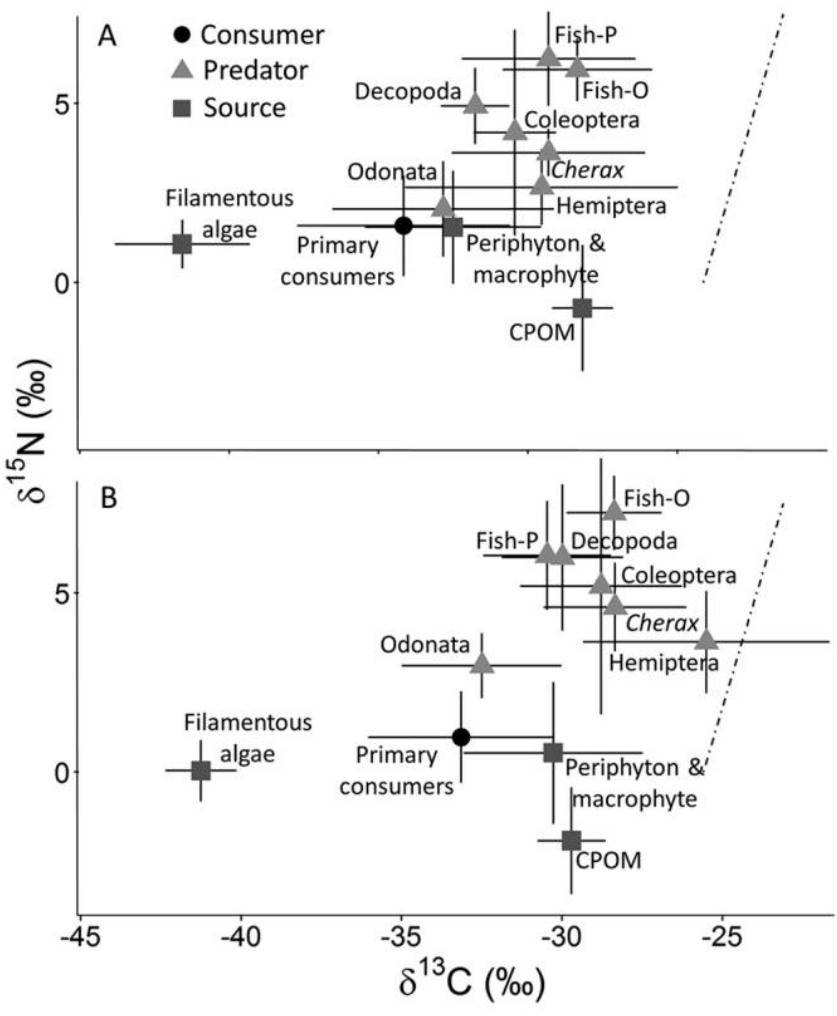

Figure 1. Mean $\left({ }^{ \pm} \mathrm{SD}\right)$ of the $\delta^{13} \mathrm{C}$ and $\delta^{15} \mathrm{~N}$ values for basal resources, primary consumers, and higher order consumers of the 5 study streams during the dry (A) and wet (B) sampling periods. Values are not corrected for trophic enrichment. The dashed line represents the estimated trophic enrichment gradient (intercept $=0$; slope $=3 / 1$, with trophic enrichment factors $\delta^{15} \mathrm{~N}=0.6$ and $\delta^{13} \mathrm{C}=0.2$ ) associated with a hypothetical algae-dependent food web centered on the global periphyton mean of $-25.7 \%$ (Ishikawa et al. 2012). CPOM = coarse particulate organic matter, Fish-P $=$ predatory fish, Fish-O = omnivorous fish.

$5.5 \%$ on average) than periphyton $\delta^{13} \mathrm{C}$ values in the dry sampling period $\left(\delta^{13} \mathrm{C}=-34.9 \%\right.$ o \pm 2.54 ) (LMM, $t=$ $6.8, p=0.002$; Fig. 2). Coupled with this $5.5 \%$ increase in periphyton $\delta^{13} \mathrm{C}$ during the wet period was a corresponding increase in mean $\delta^{13} \mathrm{C}$ values for primary consumers (LMM, $t=2.8, p=0.007$ ), predatory Coleoptera (LMM, $t=2.9, p<0.05)$, Decapoda (LMM, $t=3.5, p=0.02)$, and for the entire food web (LMM, $t=9.1, p=0.001$ ) (Fig. 2). $\delta^{13} \mathrm{C}$ values for filamentous algae, macrophytes, CPOM, Hemiptera, Odonata, Cherax, and omnivorous and predatory fish did not differ among sampling periods (LMM, $p>0.05$; Fig. 2).

In-stream primary producers contributed $>77$ and $95 \%$, on average, of primary consumers' diets during the dry and wet sampling periods, respectively (LMM; Fig. 3). Periphyton or macrophytes were the dominant basal resources for primary consumers in both sampling periods, with an estimated mean $( \pm \mathrm{SD})$ dietary contribution of $44.8 \pm$ 


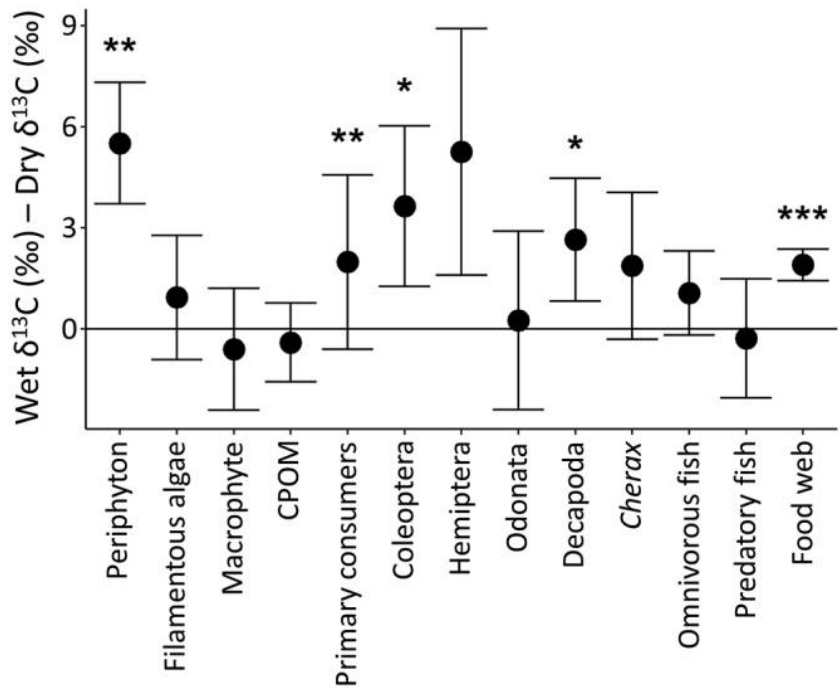

Figure 2. Mean $( \pm \mathrm{SD})$ differences in $\delta^{13} \mathrm{C}$ values for basal resources, consumers, and a foodweb average between wet and dry sampling periods. $\delta^{13} \mathrm{C}$ values $>0$ indicate a lower $\delta^{13} \mathrm{C}$ value in the dry than the wet sampling periods. $\mathrm{CPOM}=$ coarse particulate organic matter. Asterisks indicate significant differences among $\delta^{13} \mathrm{C}$ values between dry and wet sampling periods. * $p<0.05$, ** $p<0.01$, **** $p<0.001$.

$25.9 \%$ during the dry period and $66.2 \pm 14.1 \%$ during the wet period (LMM; Fig. 3). The dietary contribution from filamentous algae was consistent among sampling periods $(32.6 \pm 13.2 \%$ and $29.0 \pm 4.52 \%$ for dry and wet periods, respectively). The contribution of CPOM to primary consumer diets was relatively low but $>4 \times$ greater in the dry $(22.5 \pm 16.0 \%)$ than the wet period $(4.69 \pm 12.8 \%)(\mathrm{LMM}$; Fig. 3). Despite a greater dietary contribution of CPOM to primary consumers during the dry than wet sampling periods (Fig. 3), primary-consumer $\delta^{13} \mathrm{C}$ values did not shift toward that of CPOM from the dry to wet sampling periods (Figs 1A, B, 2). Estimated dietary contributions were very similar across the 3 TEFs used (Fig. S2A-C), and Bayesian mixing models yielded very similar mean results to those of the LMMs (Fig. S4).

\section{Biogeochemistry}

Surface water samples were high in ${ }^{222} \mathrm{Rn}$ at all study sites (Table 1). pH was circumneutral, with the mean value varying from 6.61 to 7.65 among sites and sampling periods (Table 1). Total DIC concentrations were, on average, significantly higher during the wet $(5526 \pm 388 \mu \mathrm{mol} / \mathrm{L})$ than the dry $(4755 \pm 729 \mu \mathrm{mol} / \mathrm{L})$ sampling period (LMM, $t=-2.9, p=0.01$ ). $\mathrm{HCO}_{3}{ }^{-}$constituted, on average, $81 \%$ of the total DIC concentrations at each site and was greater in the wet $(4303 \pm 445 \mu \mathrm{mol} / \mathrm{L})$ than the dry $(4004 \pm 678 \mu \mathrm{mol} / \mathrm{L})$ sampling period (LMM, $t=-2.8$, $p=0.02)$. $\mathrm{CO}_{2 \text { aq }}$ constituted, on average, $19 \%$ of the total
DIC concentrations at each site and was greater in the wet $(1220 \pm 617 \mu \mathrm{mol} / \mathrm{L})$ than the $\operatorname{dry}(747 \pm 335 \mu \mathrm{mol} / \mathrm{L}) \mathrm{sam}-$ pling period (LMM; $t=-2.8, p=0.02) . \mathrm{CO}_{3}{ }^{2-}(0.001 \%$ of total DIC) did not vary between wet and dry sampling periods (LMM; $t=1.3, p=0.23$ ). The only exception to these overall trends was for the Bremer River site, in which DIC, $\mathrm{CO}_{2}$, and $\mathrm{HCO}_{3}{ }^{-}$were greater in the dry than wet sampling period (Table 1).

Mean DIC concentrations across sites were positively correlated with the $\delta^{13} \mathrm{C}$ values of primary consumers, and the average value for the entire food web in the dry sampling period and for both sampling periods combined (Table 2). DIC concentrations were negatively correlated with the $\delta^{13} \mathrm{C}$ of filamentous algae during the wet sampling period (Table 2), but this test was limited to 3 sites. The overall correlations between mean $\mathrm{CO}_{2 \mathrm{aq}}$ concentrations and the $\delta^{13} \mathrm{C}$ value for periphyton and primary consumers were not significant (Table 2), but trends were generally negative (Fig. 4A, B). Mean $\mathrm{CO}_{2 \mathrm{aq}}$ concentrations were negatively correlated with mean $\delta^{13} \mathrm{C}$ values for the entire food web during the wet sampling period (Table 2, Fig. 4C) and with the $\delta^{13} \mathrm{C}$ value for filamentous algae during the dry sampling period (Table 2).

\section{DISCUSSION}

The productivity of the intermittent streams we studied is probably strongly linked to groundwater contributions to flow that: 1) sustain wetted environments and autotro-

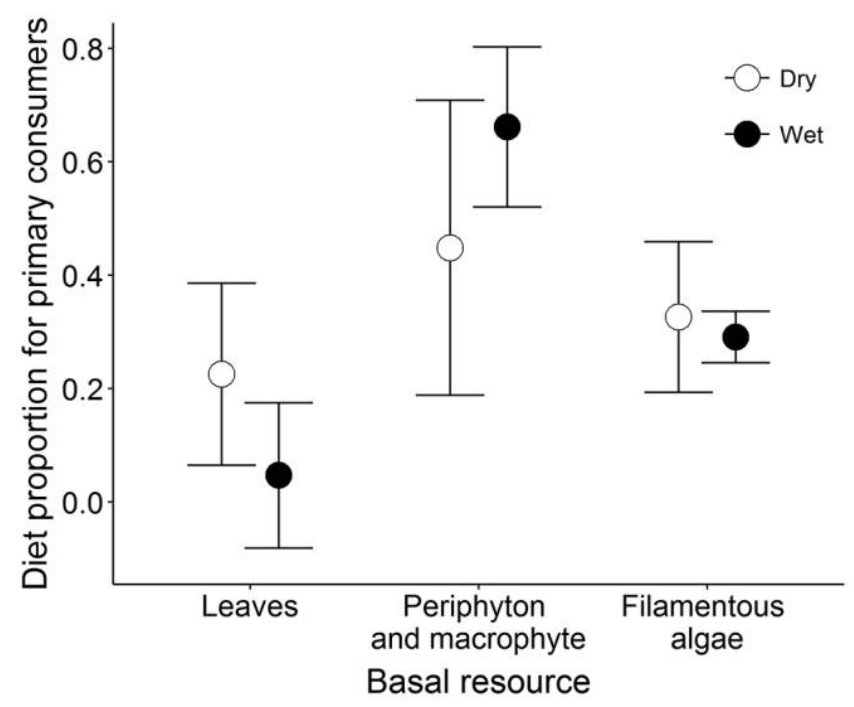

Figure 3. Mean $( \pm \mathrm{SD})$ diet proportion for primary consumers collected from 5 intermittent streams in dry and wet sampling periods. Proportions were calculated with a 3-source linear mixing model (IsoError) and represent dietary proportions from 3 pooled mixing models, each based on different trophic-enrichment factors for primary consumers $\left(\delta^{13} \mathrm{C}=0.2\right.$ and $\delta^{15} \mathrm{~N}=0.6, \delta^{13} \mathrm{C}=0.3$ and $\delta^{15} \mathrm{~N}=0.7, \delta^{13} \mathrm{C}=0.4$ and $\left.\delta^{15} \mathrm{~N}=0.8\right)$. CPOM $=$ coarse particulate organic matter. 
Table 2. Spearman's correlation coefficients of relationships between the $\delta^{13} \mathrm{C}$ of various foodweb components and dissolved inorganic C (DIC) chemistry data collected in dry and wet sampling periods and for all data combined. Significant correlations $(p \leq 0.05)$ are in bold.

\begin{tabular}{llcrrrr}
\hline Sampling period & $\begin{array}{c}\text { Foodweb component } \\
\left(\delta^{13} \mathrm{C}\right)\end{array}$ & Sample size & $\begin{array}{c}\mathrm{DIC} \\
(\mu \mathrm{mol} / \mathrm{L})\end{array}$ & $\begin{array}{c}\mathrm{CO}_{2 \mathrm{aq}} \\
(\mu \mathrm{mol} / \mathrm{L})\end{array}$ & $\begin{array}{r}\mathrm{HCO}_{3}- \\
(\mu \mathrm{mol} / \mathrm{L})\end{array}$ & $\begin{array}{r}\mathrm{CO}_{3}{ }^{2-} \\
(\mu \mathrm{mol} / \mathrm{L})\end{array}$ \\
\hline All & Periphyton & 10 & 0.49 & -0.05 & 0.60 & 0.12 \\
All & Macrophyte & 10 & -0.30 & 0.04 & -0.39 & -0.11 \\
All & Filamentous algae & 6 & -0.33 & -0.14 & 0.02 & 0.29 \\
All & Primary consumer & 10 & $\mathbf{0 . 6 4}$ & 0.01 & 0.59 & 0.05 \\
All & Food web & 10 & $\mathbf{0 . 7 6}$ & 0.01 & $\mathbf{0 . 7 9}$ & 0.16 \\
Dry & Periphyton & 5 & -0.30 & -0.30 & 0.20 & 0.40 \\
Dry & Macrophyte & 5 & 0.30 & 0.30 & -0.20 & -0.40 \\
Dry & Filamentous algae & 3 & -0.50 & $-\mathbf{1 . 0 0}$ & $\mathbf{1 . 0 0}$ & $\mathbf{1 . 0 0}$ \\
Dry & Primary consumer & 5 & $\mathbf{1 . 0 0}$ & 0.20 & 0.30 & -0.10 \\
Dry & Food web & 5 & $\mathbf{0 . 9 0}$ & 0.10 & 0.40 & 0.00 \\
Wet & Periphyton & 5 & 0.50 & -0.70 & $\mathbf{1 . 0 0}$ & 0.70 \\
Wet & Macrophyte & 5 & -0.80 & -0.40 & -0.20 & 0.40 \\
Wet & Filamentous algae & 3 & $-\mathbf{0 . 9 0}$ & 0.30 & -0.70 & -0.30 \\
Wet & Primary consumer & 5 & -0.20 & -0.50 & 0.40 & 0.50 \\
Wet & Food web & 5 & -0.30 & $-\mathbf{0 . 9 0}$ & 0.60 & $\mathbf{0 . 9 0}$ \\
\hline
\end{tabular}

phic growth during dry phases, and 2) input dissolved resources that potentially contribute to the energetic base of producers and consumers. Multiple lines of evidence indicated that autotrophic food resources were the main $\mathrm{C}$ source for primary and higher-order consumers during both drier and wetter hydrological periods. We found evidence that groundwater-delivered DIC, probably from subsurface microbial respiration, was incorporated into the biomass of primary producers and consumers. Thus, autotrophic activity in our study streams appears to be influenced by inorganic $C$ from subsurface-detrital energetic pathways in the broader catchment. Just as soil concentrations of DIC and DOC are coupled by the metabolic processes of subsurface respiration and surface photosynthesis (Shibata et al. 2001), our research highlights that autotrophic energetic pathways in streams can be linked directly to soil detrital energetic pathways through inputs of high concentrations of microbially respired $\mathrm{CO}_{2}$ in groundwater. Foodweb investigators commonly recognize that consumers obtain resources from both autotrophic and detrital pathways through the process of 'multichannel' feeding, and this factor can complicate the quantification of these energetic pathways, particularly at higher trophic positions (Polis and Strong 1996, Wolkovich et al. 2014). We use the findings from our research to highlight that a notion of 'multichannel' resource origin can apply to autotrophic organisms themselves because they can assimilate $\mathrm{C}$ originating from detrital pathways, even across environmental boundaries (i.e., DIC transport from terrestrial to aquatic environments).

\section{Groundwater-derived DIC incorporated into autotrophic and consumer biomass}

Mean $\delta{ }^{13} \mathrm{C}$ values of many foodweb components in our study were much lower (e.g., periphyton: dry $=-34.8 \%$, wet $=-29.2 \%$; primary consumers: dry $=-34.9 \%$, wet $=-33.1 \%$ ) than reported global average values, such as for periphyton (-25.7\%o; Ishikawa et al. 2012) and terrestrial detritus (C3 plant mean $\sim-27 \%$; Finlay and Kendall 2007). Several processes may contribute to the low foodweb $\delta^{13} \mathrm{C}$ values, including incorporation of $\mathrm{C}$ from $\mathrm{CH}_{4}$-oxidizing bacteria, which can lead to $\delta^{13} \mathrm{C}$ values for consumers $<-40 \%$ o (Grey 2016). However, no consumers had values this low, so it is unlikely that $\mathrm{CH}_{4}$-oxidizing bacteria were responsible for the low $\delta^{13} \mathrm{C}$ foodweb values in our study. The low $\delta^{13} \mathrm{C}$ values most probably reflect assimilation of soil-respired $\mathrm{CO}_{2}$ in groundwater by primary producers and subsequent isotopic fractionation. This $\mathrm{CO}_{2}$ pool has a much lower $\delta^{13} \mathrm{C}$ value $(\sim-23 \pm 3 \%$, in a region dominated by $\mathrm{C}_{3}$ vegetation; Gray et al. 2011) than by atmospheric $\mathrm{CO}_{2}(\sim-8 \%)$ and is often found at high concentrations in groundwater-influenced streams and rivers (Jones and Mulholland 1998, Hope et al. 2004). It is worth noting that $\mathrm{C}_{4}$ vegetation is present in southern Queensland (Hattersley 1983) and may have led to a higher $\delta^{13} \mathrm{C}$ value of soil-respired $\mathrm{CO}_{2}$ than if the landscape were completely dominated by $\mathrm{C}_{3}$ vegetation. Nonetheless, the high concentrations of groundwater-derived $\mathrm{CO}_{2}$ coupled with photosynthetic fractionation, which decreases $\delta^{13} \mathrm{C}$ by up to $29 \%$ (Roeske and O'Leary 1984), can lead to highly ${ }^{13} \mathrm{C}$-depleted values of primary producers $(<-46 \%$ ) and 

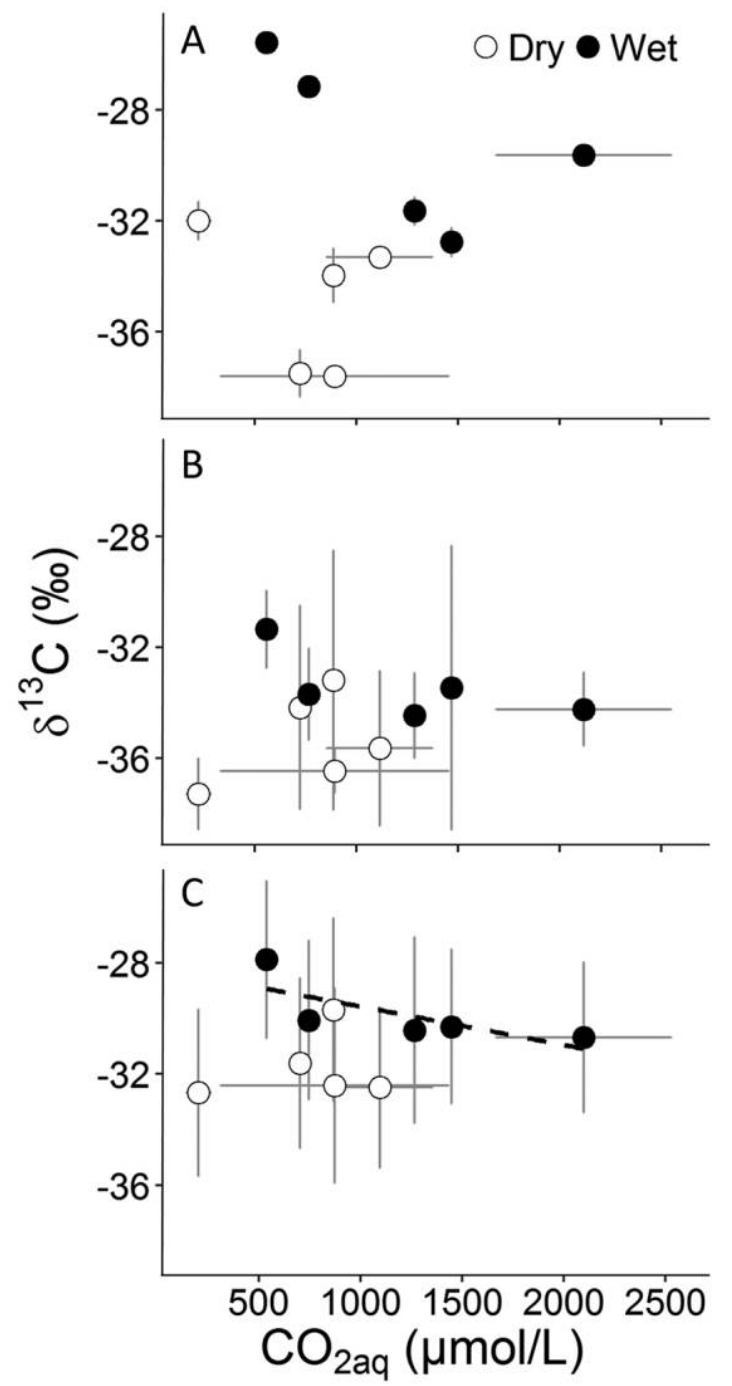

Figure 4. Mean $( \pm \mathrm{SD})$ aqueous carbon dioxide $\left(\mathrm{CO}_{2 \mathrm{aq}}\right)$ concentration and the $\delta^{13} \mathrm{C}$ of periphyton (A), primary consumers (B), and the entire food web (mean for basal resources and consumers) (C) in 5 intermittent streams during dry and wet sampling periods. A line of best fit is fitted for significant Spearman's rank-order test.

their consumers $(<-34 \%$, and down to $-43.6 \%$ ) (Rounick and James 1984, Finlay 2004, Gray et al. 2011). We recorded similarly low $\delta^{13} \mathrm{C}$ values for filamentous algae $($ mean $=-42 \%)$ and primary consumers $($ mean $=$ $-34 \%$ ) (Fig. 1A, B).

We also observed a significant negative association between $\mathrm{CO}_{2 \mathrm{aq}}$ and the $\delta^{13} \mathrm{C}$ of the entire food web during the wet sampling period, a trend indicative of incorporation of groundwater DIC into producer and consumer biomass (Finlay 2004, Gray et al. 2011). However, this negative association was based on basal food resource and consumer isotope values collected from 5 sites and further research is required to confirm this trend. Additional research should also be done to investigate the factors underpinning re- gional variation in the association between the $\delta^{13} \mathrm{C}$ of primary producers and consumers with $\mathrm{CO}_{2 \mathrm{aq}}$ concentrations, because, for example, we observed similar $\delta^{13} \mathrm{C}$ values of primary producers and consumers to those reported by Finlay (2004) but at greater $\mathrm{CO}_{2 \mathrm{aq}}$ concentrations. Different DIC acquisition strategies by algae and region-specific $\delta^{13} \mathrm{C}$ values of DIC probably contribute to variation in the $\delta^{13} \mathrm{C}$ values of primary producers.

\section{Seasonal shifts in periphyton $\delta^{13} \mathrm{C}$ values were reflected in whole food web}

Our results clearly show that periphyton was an important $\mathrm{C}$ source for primary consumers during dry periods because they and the overall food web became depleted in ${ }^{13} \mathrm{C}$ during this time. The energetic importance of periphyton during the dry period is broadly consistent with our hypothesized response and current understanding of the energy dynamics of stream ecosystems with large seasonal changes in hydrology. Periods of low flow can reduce the flux of detrital resources through the ecosystem and cause consumers to become more reliant on algal resources (Finlay et al. 2002, Bunn et al. 2003, Reid et al. 2008). However, the combined dietary contribution of periphyton and macrophytes to primary consumers, calculated based on linear and Bayesian mixing models, was lower during the dry than the wet sampling period. We suggest that this finding may be related to an observed lower prevalence and availability, and thus dietary contribution, of macrophytes during the dry sampling period. Indeed, dual-isotope plots that do not combine stable-isotope values for periphyton and macrophytes indicate that periphyton stable-isotope values were more similar to those of primary consumers than of macrophytes in the dry sampling period (Fig. S5), even though large errors and fairly similar means prevented a more precise separation of periphyton and macrophyte contributions. Regardless of changes in the dietary contribution from periphyton and macrophytes to primary consumers, the lower $\delta^{13} \mathrm{C}$ values for periphyton during the dry sampling period probably were linked to greater relative contributions of groundwater to surface water, which presumably led to lower $\delta^{13} \mathrm{C}$ values of the streamwater DIC that periphyton assimilated.

We observed a negative association between $\mathrm{CO}_{2 \mathrm{aq}}$ and $\delta^{13} \mathrm{C}$ values for the food web during the wet but not the dry sampling period. The lack of association between $\mathrm{CO}_{2 \mathrm{aq}}$ and $\delta^{13} \mathrm{C}$ values for the food web during the dry sampling period is surprising given that periphyton was still an important $\mathrm{C}$ source for primary consumers. The controls over algal $\delta^{13} \mathrm{C}$ in freshwater ecosystems are not well understood (Finlay 2004), and multiple factors could influence both $\mathrm{CO}_{2 \mathrm{aq}}$ concentrations and $\delta^{13} \mathrm{C}$ values of living biomass. Reduced flow velocity, in particular, can increase the thickness of stagnant boundary layers surrounding algal membranes, reducing passive diffusion of $\mathrm{CO}_{2 \mathrm{aq}}$ across 
membranes and leading to $\mathrm{C}$ limitation and more variable fractionation during $C$ uptake (Finlay 2004). In addition, reduced surface-water flow presumably led to greater reachscale heterogeneity in DIC concentrations, a pattern that has been observed for dissolved nutrients and organic matter (von Schiller et al. 2011, 2015). The $\delta^{13} \mathrm{C}$ value of biota may vary as a function of this reach-scale heterogeneity, and variation in biota $\delta^{13} \mathrm{C}$ values could be most evident for biota inhabiting pools with varying groundwater connectivity. Consequently, reach-scale values of $\mathrm{CO}_{2 \mathrm{aq}}$ concentrations may not be representative of measured producer and consumer $\delta^{13} \mathrm{C}$ values during the dry sampling period.

Food webs were overwhelmingly supported by sources of autochthonous primary production (i.e., periphyton, macrophytes, and filamentous algae) rather than terrestrial detritus (i.e., CPOM). Eucalypt leaves are a dominant detrital fraction in many Australian streams (Bunn 1986), but are considered a poor-quality resource for primary consumers because of their toughness, low $\mathrm{N}$ concentrations, and secondary metabolites, which include high concentrations of tannins and phenolic molecules (Watson and Barmuta 2011). In addition, successive periods of wetting and drying in intermittent streams can lead to reduced CPOM processing efficiency by microbes and detritivores once flow resumes (Dieter et al. 2011). Poor-quality detrital resources combined with the negative effects of flow intermittency may have contributed to relatively low consumption of CPOM by consumers in our intermittent study streams.

\section{Groundwater discharge enhancing stream ecosystems}

The low $\delta^{13} \mathrm{C}$ value of the entire food web indicates that respired inorganic $C$ from sub-surface microbes is a dominant source of biologically fixed inorganic C. However, the extent to which inputs of dissolved resources from groundwater limit or enhance autotrophic productivity or simply act as a label for DIC origin is still unknown. Investigators who conducted experiments in which they elevated $\mathrm{CO}_{2 \mathrm{aq}}$ concentrations above ambient concentrations reported increased stream algal biomass and production (Hu and Gao 2008, Park et al. 2016) and increased density, biomass, and average size of consumers (Hargrave et al. 2009). In contrast, Brown et al. (2017) reported no change in algal biomass over a 5 -wk $\mathrm{CO}_{2 \mathrm{aq}}$ enhancement experiment in a stream, but inorganic $\mathrm{N}$ and $\mathrm{P}$ limitation may have reduced or eliminated the effects of $\mathrm{CO}_{2 \mathrm{aq}}$ fertilization. Primary production can be co-limited by $\mathrm{CO}_{2 \mathrm{aq}}$ in unproductive lakes (Jansson et al. 2012). Therefore, groundwater inputs that elevate $\mathrm{CO}_{2 \mathrm{aq}}$ concentrations might promote primary production, especially at times of labile $\mathrm{C}$ limitation (Low-Décarie et al. 2014). However, subsurface inputs and groundwater discharge probably also deliver other dissolved resources that enhance stream productivity, such as dissolved organic matter and nutrients. Dissolved resources from groundwater discharge have been associated with enhanced rates of stream heterotrophic activity (Fellman et al. 2014) and more complex food webs (Pettit et al. 2016), and have been considered 'hotspots' for riparian plant (Kuglerová et al. 2014) and invertebrate (Gray and Harding 2009) diversity and productivity. Groundwater discharge to aquatic environments plays a critical role for maintaining, and possibly enhancing, important ecological processes while supporting diverse species assemblages that contribute to local and regional biological diversity.

\section{Research and management implications for intermittent stream food webs}

Our research uncovered strong energetic links between autotrophs and consumers during both wetter and drier hydrological phases in our intermittent study streams. Given that the presence of aquatic autotrophs is constrained by the extent of wetted habitat, prolonged periods of reduced flow (and cease-to-flow events) caused by groundwater extraction or changed climatic conditions may reduce the availability of this preferred energy source for consumers. We uncovered a strong biogeochemical link between groundwater inputs and biologically fixed $C$ in the surface water environment. Overall, the continued productivity of the intermittent aquatic food webs we studied was strongly linked to groundwater inputs that sustained surface aquatic environments during dry phases and potentially continued surface-subsurface hydrological exchange that delivered groundwater resources to surface waters. Rarely do researchers investigate the origin of the DIC that supports aquatic autotrophs or consider the role of groundwater inputs, more generally, for enhancing stream processes. We suggest that efforts should be made to understand better the spatiotemporal patterns and controls of groundwaterderived resources entering the aquatic food webs and their contribution to catchment biogeochemical processes.

\section{ACKNOWLEDGEMENTS}

Author contributions: RMB, HR, SME, MSA, NRB, and MJK designed the study. RMB, DGV, HR, SME, MSA, NRB, and MJK collected data. RMB, DGV, and HR conducted laboratory analyses. RMB, DGV, HR, MV, and BF performed data analysis and interpretation. RMB wrote the first draft of the manuscript, and all authors contributed to revisions.

We thank Luke Carpenter-Bundhoo, Clément Nicoud, Helena Vogler, Songyan Yu, Wills Brassil, and Junsong Chen for invaluable field and laboratory assistance. We also thank Neil Pettit for riparian vegetation information. Moya Tomlinson, Bruce Chessman, and Andrew Boulton provided advice on the project design and an earlier version of the manuscript. Funding for this project came from the Office of Water Science within the Australian Government Department of the Environment and Energy. The collection and tissue sampling of vertebrates was conducted in accordance with the conditions set and approved by the Griffith 
University Animal Ethics Committee (Project reference ENV/12/ 14/AEC).

\section{LITERATURE CITED}

Acuña, V., M. Hunter, and A. Ruhí. 2017. Managing temporary streams and rivers as unique rather than second-class ecosystems. Biological Conservation 211:12-19.

Andersen, M., O. Barron, N. Bond, R. Burrows, S. Eberhard, I. Emelyanova, R. Fensham, R. Froend, M. Kennard, N. Marsh, N. Pettit, R. Rossini, R. Rutlidge, D. Valdez, and D. Ward. 2016. Research to inform the assessment of ecohydrological responses to coal seam gas extraction and coal mining. Department of the Environment and Energy, Commonwealth of Australia, Canberra, Australia. (Available from: http:// www.environment.gov.au/water/publications/assessment -ecohydrological-responses)

Andrews, J. N., and D. F. Wood. 1972. Mechanism of radon release in rock matrices and entry into groundwaters. Transactions of the Institution of Mining and Metallurgy, Section B: Applied Earth Science 81:198-209.

Appelo, C. A. J., and D. Postma. 2005. Geochemistry, groundwater and pollution. 2 edition. CRC Press, Rotterdam, The Netherlands.

Bates, D., M. Maechler, B. Bolker, and S. Walker. 2015. Fitting linear mixed-effects models using lme4. Iournal of Statistical Software 67:1-48.

Ben-David, M., R. W. Flynn, and D. M. Schell. 1997. Annual and seasonal changes in diets of martens: evidence from stable isotope analysis. Oecologia 111:280-291.

Blanke, C. M., Y. Chikaraishi, Y. Takizawa, S. A. Steffan, P. S. Dharampal, and M. J. Vander Zanden. 2017. Comparing compound-specific and bulk stable nitrogen isotope trophic discrimination factors across multiple freshwater fish species and diets. Canadian Journal of Fisheries and Aquatic Sciences 74:1291-1297.

Bond, A. L., and A. W. Diamond. 2011. Recent Bayesian stableisotope mixing models are highly sensitive to variation in discrimination factors. Ecological Applications 21:1017-1023.

Brett, M. T., S. E. Bunn, S. Chandra, A. W. E. Galloway, F. Guo, M. J. Kainz, P. Kankaala, D. C. P. Lau, T. P. Moulton, M. E. Power, J. B. Rasmussen, S. J. Taipale, J. H. Thorp, and J. D. Wehr. 2017. How important are terrestrial organic carbon inputs for secondary production in freshwater ecosystems? Freshwater Biology 62:833-853.

Brown, T. R. W., E. Low-Décarie, R. W. Pillsbury, G. A. Fox, and K. M. Scott. 2017. The effects of elevated atmospheric $\mathrm{CO}_{2}$ on freshwater periphyton in a temperate stream. Hydrobiologia 794:333-346.

Bunn, S. E. 1986. Origin and fate of organic matter in Australian upland streams. Pages 277-292 in P. De Deckler and W. D. Williams (editors). Limnology in Australia. CSIRO, Melbourne, Australia.

Bunn, S. E., P. M. Davies, and M. Winning. 2003. Sources of organic carbon supporting the food web of an arid zone floodplain river. Freshwater Biology 48:619-635.

Bunn, S. E., C. Leigh, and T. D. Jardine. 2013. Diet-tissue fractionation of $\delta^{15} \mathrm{~N}$ by consumers from streams and rivers. Limnology and Oceanography 58:765-773.

Burnett, W. C., and H. Dulaiova. 2003. Estimating the dynamics of groundwater input into the coastal zone via continuous radon-222 measurements. Journal of Environmental Radioactivity 69:21-35.

Burrows, R. M., H. Rutlidge, N. R. Bond, S. M. Eberhard, A. Auhl, M. S. Andersen, D. G. Valdez, and M. J. Kennard. 2017. High rates of organic carbon processing in the hyporheic zone of intermittent streams. Scientific Reports 7:13198.

Cooper, G. M., and R. E. Hausman. 2013. The cell: a molecular approach. 6 edition. Sinauer Associates, Sunderland, Massachusetts.

DeNiro, M. J., and S. Epstein. 1978. Influence of diet on the distribution of carbon isotopes in animals. Geochimica et Cosmochimica Acta 42:495-506.

DeNiro, M. J., and S. Epstein. 1981. Influence of diet on the distribution of nitrogen isotopes in animals. Geochimica et Cosmochimica Acta 45:341-351.

Dieter, D., D. von Schiller, E. M. García-Roger, M. M. SánchezMontoya, R. Gómez, J. Mora-Gómez, F. Sangiorgio, J. Gelbrecht, and K. Tockner. 2011. Preconditioning effects of intermittent stream flow on leaf litter decomposition. Aquatic Sciences 73:599-609.

Dinsmore, K. J., M. B. Wallin, M. S. Johnson, M. F. Billett, K. Bishop, J. Pumpanen, and A. Ojala. 2013. Contrasting $\mathrm{CO}_{2}$ concentration discharge dynamics in headwater streams: a multi-catchment comparison. Iournal of Geophysical Research: Biogeosciences 118:445-461.

Fellman, J. B., R. G. M. Spencer, P. A. Raymond, N. E. Pettit, G. Skrzypek, P. J. Hernes, and P. F. Grierson. 2014. Dissolved organic carbon biolability decreases along with its modernization in fluvial networks in an ancient landscape. Ecology 95: $2622-2632$.

Finlay, J. C. 2004. Patterns and controls of lotic algal stable carbon isotope ratios. Limnology and Oceanography 49:850-861.

Finlay, J. C., and C. Kendall. 2007. Stable isotope tracing of temporal and spatial variability in organic matter sources to freshwater ecosystems. Pages 283-333 in R. Michener and K. Lajtha (editors). Stable isotopes in ecology and environmental sciences. Blackwell Publishing, Singapore.

Finlay, J. C., S. Khandwala, and M. E. Power. 2002. Spatial scales of carbon flow in a river food web. Ecology 83:1845-1859.

Gray, D., and J. S. Harding. 2009. Braided river benthic diversity at multiple spatial scales: a hierarchical analysis of beta diversity in complex floodplain systems. Iournal of the North American Benthological Society 28:537-551.

Gray, D. P., J. S. Harding, B. Elberling, T. Horton, T. J. Clough, and M. J. Winterbourn. 2011. Carbon cycling in floodplain ecosystems: out-gassing and photosynthesis transmit soil $\delta^{13} \mathrm{C}$ gradient through stream food webs. Ecosystems 14:583-597.

Grey, J. 2016. The incredible lightness of being methane-fuelled: stable isotopes reveal alternative energy pathways in aquatic ecosystems and beyond. Frontiers in Ecology and Evolution 4:1-14.

Hall, R. O., G. E. Likens, and H. M. Malcolm. 2001. Trophic basis of invertebrate production in 2 streams at the Hubbard Brook Experimental Forest. Iournal of the North American Benthological Society 20:432-447.

Hargrave, C. W., K. P. Gary, S. K. Rosado. 2009. Potential effects of elevated atmospheric carbon dioxide on benthic autotrophs and consumers in stream ecosystems: a test using experimental stream mesocosms. Global Change Biology 15:2779-2790.

Hattersley, P. W. 1983. The distribution of C3 and C4 grasses in Australia in relation to climate. Oecologia 57:113-128. 
Hope, D., S. M. Palmer, M. F. Billett, and J. J. C. Dawson. 2004. Variations in dissolved $\mathrm{CO}_{2}$ and $\mathrm{CH}_{4}$ in a first-order stream and catchment: an investigation of soil-stream linkages. $\underline{\mathrm{Hy}-}$ drological Processes 18:3255-3275.

$\mathrm{Hu}, \mathrm{H}$., and H. Gao. 2008. Impacts of $\mathrm{CO}_{2}$ enrichment on growth and photosynthesis in freshwater and marine diatoms. Chinese Journal of Oceanology and Limnology 26:407-414.

Huryn, A. D., R. H. Riley, R. G. Young, C. J. Arbuckle, K. Peacock, and G. Lyon. 2001. Temporal shift in contribution of terrestrial organic matter to consumer production in a grassland river. Freshwater Biology 46:213-226.

Ishikawa, N. F., H. Doi, and J. C. Finlay. 2012. Global metaanalysis for controlling factors on carbon stable isotope ratios of lotic periphyton. Oecologia 170:541-549.

Jansson, M., J. Karlsson, and A. Jonsson. 2012. Carbon dioxide supersaturation promotes primary production in lakes. Ecology Letters 15:527-532.

Jardine, T. D., R. J. Hunt, B. J. Pusey, and S. E. Bunn. 2011. A nonlethal sampling method for stable carbon and nitrogen isotope studies of tropical fishes. Marine and Freshwater Research 62: 83-90.

Jones, J. B., and P. J. Mulholland. 1998. Influence of drainage basin topography and elevation on carbon dioxide and methane supersaturation of stream water. Biogeochemistry 40:57-72.

Kuglerová, L., R. Jansson, A. Ågren, H. Laudon, and B. MalmRenöfält. 2014. Groundwater discharge creates hotspots of riparian plant species richness in a boreal forest stream network. Ecology 95:715-725.

Low-Décarie, E., G. F. Fussmann, and G. Bell. 2014. Aquatic primary production in a high- $\mathrm{CO}_{2}$ world. Trends in Ecology and Evolution 29:223-232.

Mackay, S. J., A. H. Arthington, and C. S. James. 2014. Classification and comparison of natural and altered flow regimes to support an Australian trial of the Ecological Limits of Hydrologic Alteration framework. Ecohydrology 7:1485-1507.

Moore, J. C., E. L. Berlow, D. C. Coleman, P. C. de Ruiter, Q. Dong, A. Hastings, N. C. Johnson, K. S. McCann, K. Melville, P. J. Morin, K. Nadelhoffer, A. D. Rosemond, D. M. Post, J. L. Sabo, K. M. Scow, M. J. Vanni, and D. H. Wall. 2004. Detritus, trophic dynamics and biodiversity. Ecology Letters 7:584-600.

Moore, J. W., and B. X. Semmens. 2008. Incorporating uncertainty and prior information into stable isotope mixing models. Ecology Letters 11:470-480.

Park, H. J., D. R. Kwon, B. H. Kim, and S. J. Hwang. 2016. Shortterm effects of elevated $\mathrm{CO}_{2}$ on periphyton community in an

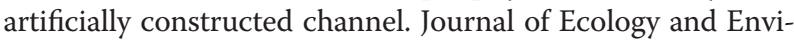
ronment 40:1-9.

Parkhurst, D. L., and C. A. J. Appelo. 2003. PHREEQC-A hydrogeochemical transport model. US Geological Survey, Reston, Virginia. (Available from: https://wwwbrr.cr.usgs .gov/projects/GWC_coupled/phreeqc/index.html)

Peel, M. C., B. L. Finlayson, and T. A. McMahon. 2007. Updated world map of the Köppen-Geiger climate classification. $\mathrm{Hy}$ drology and Earth System Sciences 11:1633-1644.

Pettit, N., D. Warfe, P. Close, B. Pusey, R. Dobbs, C. Davies, D. Valdez, and P. Davies. 2016. Carbon sources for aquatic food webs of riverine and lacustrine tropical waterholes with variable groundwater influence. Marine and Freshwater Research 68:442-451.
Phillips, D. L., and J. W. Gregg. 2001. Uncertainty in source partitioning using stable isotopes. Oecologia 127:171-179.

Polis, G. A., and D. R. Strong. 1996. Food web complexity and community dynamics. American Naturalist 5:813-846.

Raven, J. A. 1970. Exogenous inorganic carbon sources in plant photosynthesis. Biological Reviews 45:167-220.

Reid, D. J., G. P. Quinn, P. S. Lake, and P. Reich. 2008. Terrestrial detritus supports the food webs in lowland intermittent streams of south-eastern Australia: a stable isotope study. Freshwater Biology 53:2036-2050.

Roeske, C. A., and M. H. O'Leary. 1984. Carbon isotope effects on the enzyme-catalyzed carboxylation of ribulose bisphosphate. Biochemistry 23:6275-6284.

Rounick, J. S., and M. R. James. 1984. Geothermal and cold springs faunas: inorganic carbon sources affect isotope values. Limnology and Oceanography 29:386-389.

Shibata, H., H. Mitsuhashi, Y. Miyake, and S. Nakano. 2001. Dissolved and particulate carbon dynamics in a cool-temperate forested basin in northern Japan. Hydrological Processes 15: $1817-1828$.

Shurin, J. B., D. S. Gruner, and H. Hillebrand. 2006. All wet or dried up? Real differences between aquatic and terrestrial food webs. Proceedings of the Roval Society of London Series B: Biological Sciences 273:1-9.

Steward, A. L., D. von Schiller, K. Tockner, J. C. Marshall, and S. E. Bunn. 2012. When the river runs dry: human and ecological values of dry riverbeds. Frontiers in Ecology and the Environment 10:202-209.

Stock, B. C., and B. X. Semmens. 2013. MixSIAR GUI User Manual. Version 3.1. (Available from: https://github.com/brianstock /MixSIAR)

Stumm, W., and J. J. Morgan. 1996. Aquatic chemistry. $3^{\text {rd }}$ edition. Wiley and Sons, New York.

Tallaksen, L. M. 1995. A review of baseflow recession analysis. Journal of Hydrology 165:349-370.

Vannote, R. L., G. W. Minshall, K. W. Cummins, J. R. Sedell, and C. E. Cushing. 1980. The river continuum concept. Canadian Journal of Fisheries and Aquatic Sciences 37:130-137.

von Schiller, D., V. Acuña, D. Graeber, E. Martí, M. Ribot, S. Sabater, X. Timoner, and K. Tockner. 2011. Contraction, fragmentation and expansion dynamics determine nutrient availability in a Mediterranean forest stream. Aquatic Sciences 73: 485-497.

von Schiller, D., D. Graeber, M. Ribot, X. Timoner, V. Acuña, E. Martí, S. Sabater, and K. Tockner. 2015. Hydrological transitions drive dissolved organic matter quantity and composition in a temporary Mediterranean stream. Biogeochemistry 123: 429-446.

Wallace, J. B., S. L. Eggert, J. L. Meyer, and J. R. Webster. 1997. Multiple trophic levels of a forest stream linked to terrestrial litter inputs. Science 277:102-104.

Watson, A., and L. A. Barmuta. 2011. Feeding-preference trials confirm unexpected stable isotope analysis results: freshwater macroinvertebrates do consume macrophytes. Marine and Freshwater Research 62:1248-1257.

Wolkovich, E. M., S. Allesina, K. L. Cottingham, J. C. Moore, S. A. Sandin, and C. de Mazancourt. 2014. Linking the green and brown worlds: the prevalence and effect of multichannel feeding in food webs. Ecology 95:3376-3386. 